\title{
Relevansi Artikel Berita Politik Berdasarkan Query Menggunakan Term Frequency Invers Document Frequency (TF-IDF)
}

\author{
Rahmat Yanu Sutrisno ${ }^{1, *}$, Abd. Charis Fauzan ${ }^{2}$, Fadhila Nur Hanifah ${ }^{3}$, Ahmad Gufron $^{4}$, Fatra \\ Nonggala Putra ${ }^{5}$ \\ Program Studi Ilmu Komputer, Universitas Nahdlatul Ulama Blitar, Indonesia

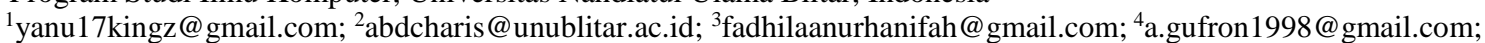 \\ 5 fatranp@unublitar.ac.id \\ * corresponding author
}

INFO ARTIKEL

Sejarah Artikel

Diterima: 6 Oktober 2019

Direvisi: 7 Februari 2020

Diterbitkan: 30 April 2020

\section{Kata Kunci}

TF-IDF

Artikel Berita Politik

Query

\section{ABSTRAK}

Politik merupakan hal yang tidak bisa dipisahkan pada manusia saat ini, baik secara langsung maupun tidak langsung. Pengaruhnya juga sangat besar dalam kehidupan manusia, mulai dari pemerintahan hingga kehidupan pribadi. Seorang Aristoteles berpendapat bahwa politik adalah bagian terpenting dalam kehidupan manusia, karena ia mempunyai pengaruh yang kuat. Tujuan penelitian ini adalah untuk mencari relevansi artikel berita politik berdasarkan query. Data yang kami gunakan berasal dari media-media online seperti Detik, dan Cnn. Hasil yang diperoleh semakin tinggi akurasi query maka semakin sering pula query tersebut muncul pada dokumen yang sebelumnya telah ditentukan

\section{PENDAHULUAN}

Politik merupakan hal yang tidak bisa dipisahkan pada manusia saat ini, baik secara langsung maupun tidak langsung. Pengaruhnya juga sangat besar dalam kehidupan manusia, mulai dari pemerintahan hingga kehidupan pribadi. seorang Aristoteles berpendapat bahwa politik adalah bagian terpenting dalam kehidupan manusia, karenia ia mempunyai pengaruh yang kuat. Mengetahui perkembangan politik yang ada di Negara sendiri sangatlah penting, karena kita akan mengetahui kemana arah Negara ini akan berjalan. Terlebih pada era modern saat ini, politik begitu cepat menyebar ke semua elemen masyarakat melalui situs-situs online seperti website, aplikasi media sosial, dll. Bagi generasi 80 an hingga generasi milenial tentu media sosial bukan hal yang baru, terutama bagi mereka yang kuliah atau bekerja di dunia komputer. Perkembangan teknologi komputer begitu cepat terutama setelah memasuki abad ke-21. Pada akhir-akhir ini peningkatan fasilitas yang dimiliki oleh komputer sangatlah beragam, mulai dari kecepatan processor, besarnya kapasitas hardisk hingga semakin canggihnya aplikasi-aplikasi yang ada di dalamnya. Semakin canggihnya teknologi tentu semakin mempermudah pekerjaan manusia, terutama di bidang komputer. Berbagai metode yang ditawakan oleh aplikasi komputer pun beragam, salah satunya adalah metode TF-IDF [1].

TF-IDF sendiri merupakan suatu cara atau teknik dalam pemilihan kata yang digunakan untuk mencari query tertentu [2]. Tidak hanya itu, TF-IDF juga bisa diterapkan untuk mencari karya ilmiah dengan standar tertentu yang sebelumnya telah ditentukan, pada penerapan di bidang lain, TF-IDF juga dapat berkolaborasi dengan twitter untuk meringkas trending topik. [3]. Pada kali ini kami akan menerapkan TF-IDF untuk mencari quey yang telah ditentukan sebelumnya. Pada penelitian terdahulu Fitri [4], telah menerapkan TF-IDF untuk pencarian dokumen berbahas Indonesia. TF-IDF juga dapat diterapkan dalam aplikasi kitab undang- 
undang hukum dasar [5]. Sedangkan pada bidang ilmu agama, TF-IDF dapat digunakan untuk mengetahui syarah hadist [6]. Tidak hanya itu, pembobotan kata yang merupakan bagian dari TF-IDF juga bisa diterapkan untuk perangkingan dokumen Al-Qur' an [7]. TF-IDF juga dapat digunakan untuk mencari karya ilmiah dengan parameter yang telah ditentukan sebelumnya [8].

\section{METODE}

Penerapan metode TF-IDF untuk mencari relevansi dokumen dalam artikel berita tentang politik menggunakan metode seperti pada Gambar 1.

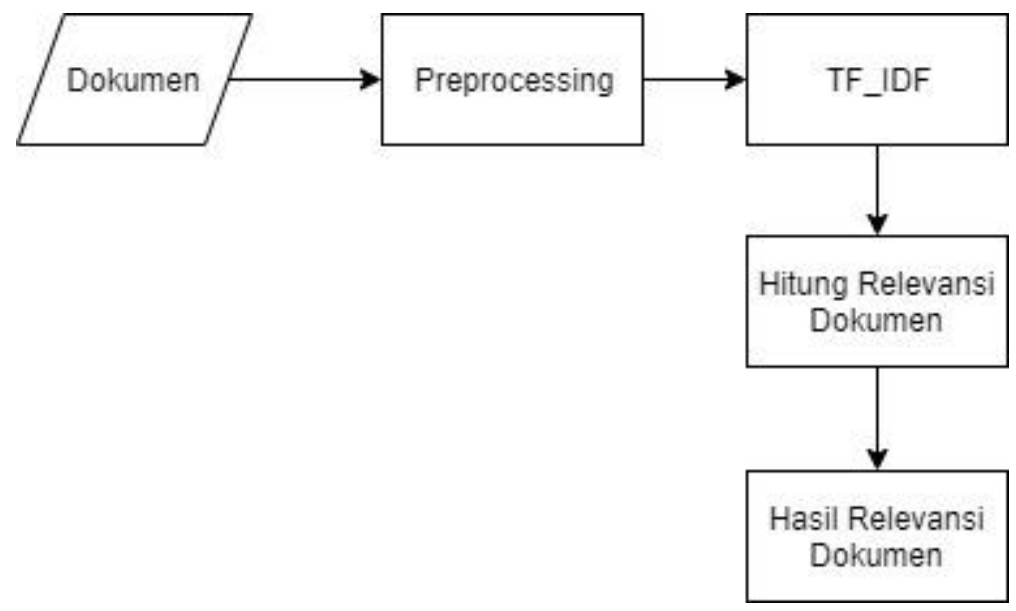

Gambar 1. Proses Metode Relevansi TF-IDF

Proses untuk Relevansi Dokumen ditampilkan pada Gambar 1. Hal pertama yaitu menyiapkan dokumen yang akan dilakukan relevansi, penelitian ini menggunakan 10 dokumen untuk dianalisis. Kemudian 10 dokumen tersebut akan dilakukan preprocessing, dilanjutkan dengan menghitung dengan metode TF-IDF, setelah itu menghitung relevansi dan hasil relevansi dari 10 dokumen tersebut [9].

\section{Pra Pemrosesan}

Preprocessing merupakan suatu proses sebelum dilakukan analisis pada dokumen untuk meminimalisir adanya dokumen yang kurang sempurna dan gangguan pada dokumen. Gambar 2 adalah langkah-langkah preprocessing. 


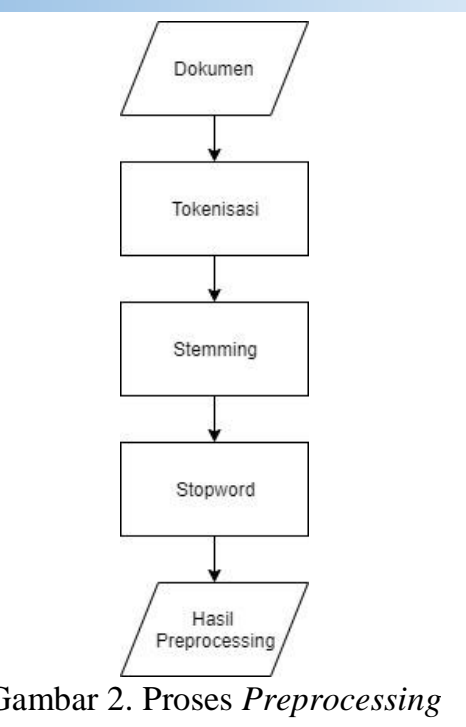

Pada penelitian ini menggunakan 10 dokumen yang akan dilakukan preprocessing seperti dijelaskan pada Gambar 2. Dari dokumen akan dilakukan tokenisasi, kemudian proses Stemming, lalu melakukan stopword dan berakhir pada hasil preprocessing [11][12]. Macam-macam preprocessing yang akan digunakan pada penelitian ini adalah:

1. Tokenisasi. Setelah mendapatkan dokumen yang akan dianalisis akan dilakukan Tokenisasi yaitu proses untuk membagi teks yang dapat berupa kalimat, paragraf atau dokumen, menjadi token - token / bagian - bagian tertentu.

2. Stemming. Kemudian sesudah tokenisasi dilakukan proses Stemming yaitu membuat kata (term) yang ada pada dokumen menjadi kata dasar, dengan menghilangkan semua imbuhan yang ada pada kata tersebut (imbuhan meng-, me-, kan-, di- , i, pe, peng-, a-, dll.).

3. Stopword. Menghilangkan kata umum (common words) yang biasanya muncul dalam jumlah besar dan dianggap tidak memiliki makna diantaranya "yang", "di", "ke".

Setelah dilakukan proses preprocessing selanjutnya mencari relevansi dokumen menggunakan metode TF-IDF [6].

\section{Perhitungan TF-IDF}

Pada algoritma $T F / I D F$ digunakan rumus untuk menghitung bobot (W) masing-masing dokumen terhadap kata kunci dengan rumus yaitu :

$$
W d t=t f d t * I D F t
$$

Dari Persamaan 1, dapat diketahui dalam rumus TF-IDF, dimana :

$\mathrm{Wdt}=$ bobot dokumen

tfdt = banyaknya kata yang dicari pada sebuah dokumen

Idft = Inversed Document Frequency $(\log (\mathrm{N} / \mathrm{df}))$

$\mathrm{N} \quad=$ total dokumen

df $\quad=$ banyak dokumen yang mengandung kata yang dicari.

\section{HASIL DAN PEMBAHASAN}

Dari hasil testing program, didapatkan program berjalan dengan lancar dan menghasilkan output yang sesuai dengan perhitungan. Adapun perhitungan data testing yang dilakukan sebagai berikut:

Kata kunci = mahasiswa, jokowi, perppu, Indonesia, KPK. 
Dokumen 1

Jakarta, CNN Indonesia -- Sebanyak 66 pelanggar jalur sepeda diberi sanksi tilang pada hari pertama pemberlakuan tilang. Mayoritas pelanggar adalah pengendara sepeda motor.

Kepala Subdirektorat Penegakkan Hukum Direktorat Lalu Lintas Polda Metro Jaya Komisaris Fahri Siregar mengatakan jumlah ini belum diakumulasikan dengan pelanggar yang ditilang Dinas Perhubungan.

"Ruas jalur sepeda yang paling banyak terjadi pelanggaran ada ruas Jalan Medan Merdeka Selatan," kata Fahri dalam keterangan tertulisnya.

Gambar 3. Dokumen (1)

Setelah dokumen diinputkan, program melakukan tokenizing yaitu pemotongan string input berdasarkan tiap kata yang menyusunnya dan stopword yaitu pembuangan kata yang tidak penting dan tanca baca, sehingga akan diperoleh :

Tabel 1. Bobot dokumen

\begin{tabular}{|c|c|c|c|c|c|c|c|c|c|c|c|}
\hline & \multicolumn{10}{|c|}{ tf } & \multirow{2}{*}{ df } \\
\hline Q & D1 & D2 & D3 & D4 & D5 & D6 & D7 & D8 & D9 & D10 & \\
\hline Mahasiswa & 0 & 0 & 0 & 0 & 0 & 2 & 0 & 0 & 1 & 0 & 2 \\
\hline KPK & 0 & 0 & 0 & 5 & 4 & 0 & 0 & 0 & 2 & 0 & 3 \\
\hline Jokowi & 0 & 2 & 2 & 2 & 0 & 0 & 0 & 0 & 1 & 2 & 5 \\
\hline Perppu & 0 & 0 & 0 & 2 & 0 & 0 & 0 & 0 & 4 & 0 & 2 \\
\hline Indonesia & 1 & 3 & 1 & 1 & 0 & 1 & 4 & 0 & 1 & 6 & 8 \\
\hline & & & & & & & & & & & \\
\hline
\end{tabular}

Tabel 2. Hasil TF-IDF

\begin{tabular}{|c|c|c|c|c|c|c|c|c|c|c|c|c|}
\hline \multirow{2}{*}{$\mathrm{D} / \mathrm{df}$} & \multirow[b]{2}{*}{ IDF } & \multirow[b]{2}{*}{ IDF+1 } & \multicolumn{10}{|c|}{$w=t f^{*}(I D F+1)$} \\
\hline & & & D1 & D2 & D3 & D4 & D5 & D6 & D7 & D8 & D9 & D10 \\
\hline 5 & 0,699 & 1,699 & 0 & 0 & 0 & 0 & 0 & 3,3979 & 0 & 0 & 1,699 & 0 \\
\hline 3,33333333 & 0,5229 & 1,5229 & 0 & 0 & 0 & 7,6144 & 6,0915 & 0 & 0 & 0 & 3,0458 & 0 \\
\hline 2 & 0,301 & 1,301 & 0 & 2,6021 & 2,6021 & 2,6021 & 0 & 0 & 0 & 0 & 1,301 & 2,6021 \\
\hline 5 & 0,699 & 1,699 & 0 & 0 & 0 & 3,3979 & 0 & 0 & 0 & 0 & 6,7959 & 0 \\
\hline 1,25 & 0,0969 & 1,0969 & 1,0969 & 3,2907 & 1,0969 & 1,0969 & 0 & 1,0969 & 4,3876 & 0 & 1,0969 & 6,5815 \\
\hline \multicolumn{3}{|c|}{ JUMLAH } & 1,0969 & 5,8928 & 3,699 & 14,711 & 6,0915 & 4,4949 & 4,3876 & 0 & 13,939 & 9,1835 \\
\hline
\end{tabular}

Setelah bobot (W) masing-masing dokumen diketahui, maka dilakukan proses pengurutan di mana semakin besar nilai $W$, semakin besar tingkat similaritas dokumen tersebut terhadap kata kunci, demikian sebaliknya. Dari Tabel 1 dan 2 di atas didapat nilai dari masing-masing dokumen sesuai dengan kata kunci yang telah digunakan, dan diperoleh dokumen yang memiliki bobot tertinggi ada pada dokumen 4 (D4) dengan total bobot 14,711.

\section{KESIMPULAN}

Berdasarkan hasil analisis Sistem Temu Kembali Informasi dengan menggunakan metode TF-IDF maka dapat ditarik kesimpulan bahwa metode TF-IDF memiliki pembobotan kata 
yang akurat pada query tertentu yang sebelumnya telah ditetapkan. Keakuratan hasil dari metode TF-IDF ini terbukti secara ilmiah karena melalui perhitungan-perhitungan dengan rumus yang telah ditunjukkan diatas. TF-IDF juga terbukti berhasil diterapkan pada bidang politik untuk mencari relevansi artikel berita yang berdasarkan query, sehingga peneltian diatas dapat memudahkan siapa saja yang mau menerapkan metode TF-IDF ke dalam bidang politik. Pada tabel diatas juga dapat ditarik kesimpulan bahwa semakin tinggi akurasi query maka semakin sering pula query tersebut muncul dari dokumen yang ada, dan semakin rendah akurasi query yang ada maka semakin jarang pula query tersebut muncul pada dokumen yang telah ditentukan sebelumnya. Adapun tahapan-tahapan sebelum menentukan query adalah dengan proses tokenisasi, yaitu proses pembagian kata menjadi token-token tertentu. Setelah melalui proses tokenisasi tahap selanjutnya yaitu Stemming, merupakan tahap menghilangkan imbuhan-imbuhan tertentu. Pada tahap terakhir sebelum mendapatkan query adalah tahapan stopwords, yaitu tahapan menghilangkan kata yang tidak memiliki arti seperti yang, di, ke, dll.

\section{REFERENSI}

[1] M. A. Rofiqi, A. C. Fauzan, A. P. Agustin, and A. A. Saputra, "Implementasi Term-Frequency Inverse Document Frequency ( TF- IDF ) Untuk Mencari Relevansi Dokumen Berdasarkan Query,' J. Comput. Sci. Appl. Informatics, vol. 1, no. 2, pp. 58-64, 2019.

[2] Okfalisa and A. H. Harahap, "Implementasi Metode Term Frequency-Inverse Document Frequency (TF-IDF) Dan Maximum Marginal Relevance Untuk Monitoring Diskusi Online,” J. Sains, Teknol. dan Ind., vol. 13, no. 2, pp. 151-159, 2016.

[3] W. Saefudin, A. Komarudin, and R. Ilyas, "Visualisasi Kumpulan Berita Dalam Bentuk Peta Digital Dengan Metode Term Frequency- Inverse Document Frequency dan Gazetteer,” pp. 665-670, 2019.

[4] M. Fitri, "Perancangan Sistem Temu Balik Informasi Dengan Metode Pembobotan Kombinasi Tf-Idf Untuk Pencarian Dokumen Berbahasa Indonesia," J. Sist. dan Teknol. Inf., vol. 1, no. 1, pp. 1-6, 2013.

[5] H. W. A. Kesuma, "Penerapan Metode TF-IDF dan Cosine Similarity dalam Aplikasi Kitab UndangUndang Hukum Dagang," 2016.

[6] V. Amrizal, "Penerapan Metode Term Frequency Inverse Document Frequency (Tf-Idf) Dan Cosine Similarity Pada Sistem Temu Kembali Informasi Untuk Mengetahui Syarah Hadits Berbasis Web (Studi Kasus: Hadits Shahih Bukhari-Muslim)," J. Tek. Inform., vol. 11, no. 2, pp. 149-164, 2018.

[7] Kurniawati, "Term weighting berbasis indeks kelas menggunakan metode tf.idf.ics," Term Weight. Berbas. Indeks Kelas Menggunakan Metod. TF.IDF.ICSF Untuk Perengkingan Dok. Al-Quran, 2016.

[8] A. A. Maarif, "Penerapan Algoritma TF-IDF untuk Pencarian Karya Ilmiah,” Dok. Karya Ilm.| Tugas Akhir| Progr. Stud. Tek. Inform. - S1| Fak. Ilmu Komput.| Univ. Dian Nuswantoro Semarang, no. 5, p. 4, 2015.

[9] Y. Yunitasari, "Penerapan Metode Eucliean Distance Untuk Ekstraksi Ciri Dokumen dan Kemiripan Dokumen," p. 5, 2019.

[10] A. Winardi, "Artikel Skripsi Universitas Nusantara PGRI Kediri ANALISIS PENERAPAN METODE," Ekon. Akunt., pp. 1-13, 2016.

[11] F. N. Putra, A. Effendi, and A. Z. Arifin, "Pembobotan Kata berdasarkan Kluster untuk Peringkasan Otomatis Multi Dokumen,” J. Linguist. Komputasional, vol. 1, no. 1, pp. 17-22, 2018.

[12] F. N. Putra and C. Fatichah, "Klasifikasi jenis kejadian menggunakan kombinasi NeuroNER dan Recurrent Convolutional Neural Network pada data Twitter," Regist. J. Ilm. Teknol. Sist. Inf., vol. 4, no. 2, pp. 81-90, 2018. 